\title{
Asking Too Much? Civility vs. Pluralism
}

\begin{abstract}
Alison Reiheld
ABSTRACT:

In a morally diverse society, moral agents inevitably run up against intractable disagreements. Civility functions as a valuable constraint on the sort of behaviors which moral agents might deploy in defense of their deeply held moral convictions and generally requires tolerance of other views and political liberalism, as does pluralism. However, most visions of civility are exceptionless: they require civil behavior regardless of how strong the disagreement is between two members of the same society. This seems an excellent idea when those required to do the tolerating might otherwise smash us. However, the demands of civility are universal and fall upon everyone, including ourselves. They may seem to require us to tolerate the intolerable, leading us not into pluralism but rather into functional relativism, and also require the powerless to moderate their demands for redress. They also place moral agents in a very difficult position with respect to realizing our deeply held moral values. Isaiah Berlin's pluralism, by contrast, allows us to violate tolerance when we come up against values which, put into practice, are incompatible with a form of life we can tolerate. Despite the many fronts on which civility and pluralism align, they are also pitted against each other. Only a qualified (not exceptionless) civility based in respect for persons can cohere with pluralism and thus resolve the double bind in which the moral agent seemed to be placed by exceptionless civility. I develop a rule for Accepted Exceptions that helps to explain how moral agents can be civil, value pluralism, demand redress, and maintain their own deeply held moral commitments.
\end{abstract}




\title{
Asking Too Much? Civility vs. Pluralism
}

\author{
Alison Reiheld, Southern Illinois University - Edwardsville \\ areihel@siue.edu
}

\section{Introduction}

In a morally diverse society, moral agents will face intractable disagreements. Civility is a valuable constraint on the behaviors moral agents might deploy in defense of deeply held moral convictions. Consider the general view, even amongst those who share many of Westboro Baptist church's anti-gay beliefs, that it is nonetheless uncivil and therefore wrong for Westboro to protest at childrens' schools and individuals' funerals (Ruane; Silvey). However, the demands of civility do not fall only on those with conservative values but also upon those with liberal and progressive values. It is tempting to say that others are simply wrong, that "we"-whomever "we" may be-are correct. Suppose we are feminists. We might even agree with a paraphrase of Barry Goldwater's famous line ${ }^{1}$ : extremism in the defense of feminism is no vice. Yet civility demands moderation of all, of "us" as well as of "them." Indeed, it may be one of the constraints which prevents a culture war ${ }^{2}$ from becoming a civil war.

\footnotetext{
1 "Extremism in the defense of liberty is no vice."

2 The term "culture war" originated in German Otto von Bismarck's quest to "defend" Germany against the power of the Catholic church in a struggle running from 1871-1878 termed kulturkampf. In 1920's Europe, Antony Gramsci advocated a "war of position" against capitalist control of media and ideas to win the masses over to anticapitalist ideals, presenting a persuasive alternative intellectual and moral view (in November of 2013, Pope Francis urged Catholics to reject the value system of capitalism and presented a struggle between the most important Catholic values such as mercy, and those which derive from market forces). Sociologist James Davison Hunter, in 1991, described a "culture war" in America between two definable polarities on a wide array of issues ranging from abortion to gay rights and including gun politics as well as separation of church and state, arguing that these go together as coherent sets, what philosophers would call "worldviews" in opposition to each other. In 1992, Pat Buchanan instantiated this analysis when he said at the Republican National Convention, "There is a religious war going on in our country for the soul of America. It is a cultural war, as critical to the kind of nation we will one day be as was the Cold War itself... The agenda [Bill] Clinton and [Hillary] Clinton would impose on America-abortion on demand, a litmus test for the Supreme Court, homosexual rights, discrimination against religious schools, women in combat-that's change, all right... It is not the kind of change America needs." Later, Buchanan said the conflict was about fundamental notions of right and wrong. The very notion of a culture war, whether or not one is being waged, sets values in opposition to each other in a morally diverse society.
} 
If we truly value pluralism in a morally diverse society, we will have to moderate our behavior in advocacy of our most deeply held values and, at some level, tolerate those with whom we have profound moral disagreements. In this sense, pluralism and civility work in harness. Yet an exceptionless civility asks too much of moral agents. It can be used as a tool to suppress dissent or questioning of current social arrangements. Indeed, it may lead not to pluralism but to a simplistic and functional moral relativism. I argue for what I see as a tension between pluralism and civility, in the process providing several different ways of thinking about civility which seem to demand that moral agents may not violate civility no matter the cost, a claim which pluralism does not make. I seek to problematize the relationship between pluralism and civility. However, I also argue that only by conceiving of civility as respect for persons, and allowing exceptions to the demands of civility, can we achieve pluralism and question existing power structures as well as belief structures which are intolerable. A qualified civility qua respect for persons is a notion of civility which can cohere with pluralism and thus resolve the double bind in which the moral agent seems to be placed, caught between commitment to deeply held personal values and commitment to civility and pluralism in a morally diverse society in which real power differentials affect who demands civility of whom.

\section{Pluralism and Civility}

"Civility" is a term tossed around with uncritical abandon in public discourse. When Rush Limbaugh referred to Sandra Fluke as a "slut" for advocating contraceptive access, he was roundly critiqued for his incivility. Major advertisers on his radio show pulled their sponsorship in protest

(Bingham). Georgetown University explicitly backed Fluke over Limbaugh “for civility's sake” (Prothero). But when we use this term, what exactly do we mean by it? What does it demand of us? And why does it seem so often to come up in the context of pluralism and moral disagreement? 
Let us begin with a consideration of pluralism. For this investigation, I use Isaiah Berlin's view. In Berlin's final essay, he is careful to distinguish between pluralism and relativism, as he always was in his work on values pluralism:

I came to the conclusion that there is a plurality of ideals, as there is a plurality of cultures and of temperaments. I am not a relativist; I do not say "I like my coffee with milk and you like it without; I am in favor of kindness and you prefer concentration camps"-each of us with his own values, which cannot be overcome or integrated. This I believe to be false. But I do believe that there is a plurality of values which men [sic] can and do seek, and that these values differ. There is not an infinity of them: the number of human values, of values that I can pursue while maintaining my human semblance, my human character, is finite-let us say 74 , or perhaps 122 , or 26 , but finite, whatever it may be. And the difference it makes is that if a man pursues one of these values, I, who do not, am able to understand why he pursues it or what it would be like, in his circumstances, for me to be induced to pursue it. Hence the possibility of human understanding... If I am a man or a woman with sufficient imagination (and this I do need), I can enter into a value system which is not my own, but which is nevertheless something I can conceive of men [sic] pursuing while remaining human.

Berlin sees the differences between humans as part of what it is to be human. Were he thinking in Heideggerian terms, he might consider moral imagination of diversity as a feature of da-sein, ontologically inseparable from Being Human and thus from human beings.

What comes of this? As Berlin puts it, "toleration and liberal consequences follow." Yet for Berlin, this is not all there is to pluralism: "if I pursue one set of values, I may detest another, and may think it is damaging to the only form of life that I am able to live or tolerate, for myself and others; in which case I may attack it... But I still recognize it as a human pursuit." Ah, how convenient it would be if the fact that someone's beliefs negated tolerable forms of life also negated the need to respect it as a human pursuit. And yet something is negated: tolerance. Berlin acknowledges we may even have to "go to war against" those who act on such beliefs, i.e. the Nazis. 
This poses a potential problem. Just as masculinist and patriarchal ideologies are arguably incompatible with forms of life which are good for women (and for men), so too any of the many feminisms are arguably incompatible with forms of life which masculinists and patriarchists value most highly. It is folly to ignore that many folks who hold masculinist and patriarchist values actually believe that it is better for both women and men, and for children, to have clearly delineated traditional general roles: women should rear children and maintain the home while men should deal with the harsh realities of politics and business, thereby look after the welfare of their women and children. Yet these values are in conflict with feminist values such as that women should have equal pay for equal work, should be able to choose whether to work in the home or outside it, and to have their work valued by society at large whether it be paid work or unpaid caregiving. These sets of "should" are incompatible with each other. Yet both groups of moral agents may consider these to be deeply held moral commitments. How do we navigate values pluralism when two sets of values are each seen by the other's adherents as incompatible with tolerable forms of life, rather than merely distinct from one's own?

We have gleaned two issues so far: Berlin's limited toleration in the face of values pluralism, and the threat that our values pose to others as well as theirs to us. Let us keep these in mind as we consider civility, its justifications, and its demands. And especially as we then move on to consider its exceptions.

\section{Visions of Civility, Power, and the Problems of Exceptionless Civility}

Let us consider some quite basic notions of civility, first by example and then in theory. One of the best-known recent examples of public civility is the May 2012 pledge between Scott Brown and Elizabeth Warren. Brown and Warren, as you may recall, were both running for the Senate seat formerly held by Ted Kennedy. Brown, the incumbent, was a fairly moderate Republican. Warren, the 
challenger, was an Ivy League professor who spear-headed the Obama Administration's consumer protection efforts. Both had strong opinions, often quite different, on major hot-button issues. However, they famously both agreed to avoid so-called "negative" campaigning. This was a commitment by each not to distort each other's positions for effect. Though the pledge did not apply to third parties, it made a difference in tone as they debated and campaigned, and the commitment lasted through much of the campaign.

Another practical example is the proposed civility pledge developed in concert by Mark DeMoss (a conservative evangelical PR executive) and Lanny Davis (a Jewish liberal democrat who defended Clinton from impeachment charges). DeMoss reached out to Davis in January of 2009 "because of alarm over what he saw as the increasingly vicious tone in American politics." (Goodstein) They asked members of Congress and every sitting Governor to swear the following ${ }^{3}$ :

I will be civil in my public discourse and behavior.

I will be respectful of others whether or not I agree with them.

I will stand against incivility when I see it.

Now that we have some concrete examples to anchor us, we can move from practice to theory. It will serve us well to build ontological distinctions between different notions of civility, all of which are nonetheless compatible with the examples of civility just provided.

\footnotetext{
${ }^{3}$ In 2011, DeMoss quite the Civility Project he and Davis founded because only three legislators had signed the pledge. In quitting, DeMoss said "I must admit to scratching my head as to why only three members of Congress, and no governors, would agree to what I believe is a rather low bar." DeMoss said he was particularly surprised by the hostility to the pledge from conservatives, who see civility with their opposition as caving in: "This political divide has become so sharp that everything is black and white, and too many conservatives can see no redeeming value in any liberal or Democrat. That would probably be true about some liberals going the other direction, but I didn't hear from them... whether or not incivility today is worse than it's been in history, it's all immaterial. It's worse than it ought to be." (Goodstein)
} 
Richard Boyd has delineated two related but distinct connotations of "civility." First, there is Formal Civility. This governs face-to-face interactions in daily life. It involves etiquette, manners, and other social norms. It is literally conventional, embodying the established conventions of a particular society. Since conventions differ between societies, so too can formal civility (Boyd 864). Michael Oakeshott has suggested that civility requires form without specifying content so that individuals can pursue their self-chosen ends. Paired with Boyd's notion of formal civility, Oakeshott's claim helps us to see how it is that formal civility is so often paired with pluralism since it is seen as structuring a society in which individuals can pursue self-chosen ends. However, this emphasis on form can present problems as we shall soon see. Anticipating this, Boyd gives us a second connotation of civility which he calls Substantive Civility. Thistype most clearly pertains to how we handle moral diversity from a pluralist standpoint since it has to do with "...standing or membership in the political community with its attendant rights and responsibilities" (ibid.). Without standing, one's right to be heard and be allowed to pursue one's own notion of the good evaporates. Boyd goes on to suggest that it is Substantive Civility which gives rise and force to Formal Civility (ibid.).

To that end, let us go beyond Boyd's basic notion of Substantive Civility to consider specific grounds of civility. I contend that the literature on civility lays out two twin Substantive Purposes of Civility. One, that it makes society work, and two, that it embodies respect for persons; this latter form most directly ties in with Berlin's humanist pluralism.

The first Substantive Purpose of Civility - that it makes society work - can be found in a number of influential works in political philosophy. Martha Nussbaum, writing on the political implications of Stoicism, claims that "No theme is deeper in Stoicism than the damage done by faction and local allegiances to the political life of a group." (Nussbaum 8) Amy Guttman and Dennis Thomson echo this concern in their excellent book Democracy and Disagreement: Why Moral Conflict Cannot Be Avoided in 
Politics, and What Should Be Done About It. Guttman and Thomson lay out the very notion of deliberative democracy, arguing that a necessary element of making this system work is that, "when citizens or their representatives disagree morally, they should continue to reason together to reach mutually acceptable decisions." (1) Lucian Pye, writing on differing notions of civility in Asia and the West-broadly construed, of course-finds a cross-cultural commonality in the purpose of civility even as its formal elements and conventions differ wildly. Pye suggests that "When civility [in whatever form it takes in different societies] totally breaks down, society ceases to exist. When civility is strong and widely upheld, the society will be integrated and coherent" (765) With respect to our current line of inquiry, Pye goes on to claim that, "Pluralistic democracy, especially when it involves rival moral concepts, requires an exceptionally high level of civility" (766). Even Hobbes and Hume can fit under this umbrella of civility qua social stability. Both have notions of civility related to what they see as proper politics. To paraphrase Hobbes in Book II of Leviathan, woe betide the person who does not choose the integrity of society over her own concerns. The alternative is life in a state of nature: nasty, brutish, solitary, and short. Hobbes would see civility as necessary for life in a political community or "civil association." Hume, though in other ways quite different from Hobbes, said that one of the most valuable of all political ideas is "the mutual deference of civility, which leads us to resign our own inclinations to those of our companions" (Hume 126). Those who see civility as a necessary condition for social stability, and who see social instability as anathema, will allow few or no exceptions to civility's demands of tolerance and compromise.

However, we get a different kind of mileage out of the second strain of arguments on the Substantive Purpose of Civility - that it embodies respect for persons. This alternative allows us to see where Rush Limbaugh went awry when he called Sandra Fluke a "slut", and went awry in fundamentally moral terms rather than in consequentialist ones concerned with the stability of society. P.M. Forni, long with the Johns Hopkins Civility Project, argues strongly that, "The extraordinary relevance of the 
rules of civility to our lives is that by following them we put into everyday practice the principle of respect for persons ${ }^{4}$." (13) Similarly, Robert George argues that, by listening genuinely to the positions of others and taking moral disagreement seriously, one is not showing respect for a position so much as respect for the person who happens to hold that position (1398). And Michael McConnell claims that good citizens are "...[those] who learn to love the good and to recognize and respect visions of the good in others" (84). These notions of civility qua respect for persons emphasize an entirely different substantive purpose of civility.

Both substantive types of civility-social stability and respect for persons-give rise to a demand for formal civility. After all, formal civility is how we behave in order to preserve the ground of civility, whatever it may be. And both can, though need not, give rise to a demand that all persons abide by the norms of formal civility in all cases. As we shall see, this can prove deeply problematic and is one feature of civility which I argue against. Let us consider how this demand arises.

Civility qua respect for persons presents a special difficulty for visions of the good which not only differ-as between feminisms-but which pose a threat to the form of life a moral agent holds dear. Consider again the threat that patriarchal value systems pose to feminisms, and the reverse. Civility qua respect for persons demands that we treat decently the person who holds views we find anathema. It can give rise to exceptionless demands, as when Forni says, "I simply cannot conceive of any circumstances in our own daily lives when it would be appropriate or advantageous to be rude or boorish. The powerful combination of self-respect and respect for others should make it almost impossible for us to choose incivility... To brawl is human. To be civil works." Civility qua social stabilizer, in its most Hobbesian form, also brooks no exception lest the alternative to a non-ideal

\footnotetext{
${ }^{4}$ Forni acknowledges other conceptions of civility when he mentions that, from some perspectives, "Choosing civility means choosing to do the right thing for others-for the 'city'." However, he overwhelmingly focuses on respect for persons in most of his " 25 rules of considerate conduct."
} 
society be no society at all. Hume contends that "a good-natured man... practices this civility to every mortal, without premeditation or interest." I call such an absolute conception Exceptionless Civility: the position that it is morally wrong and/or social suicide to manifest incivility no matter the cost to a moral agent's other moral commitments. Both of the substantive forms of civility I have identified-qua respect for persons, and qua social stabilizer-can be argued to give rise to Exceptionless Civility.

All Exceptionless Civilities levy powerful demands on moral agents with respect to our ability to realize our deeply held personal values in the face of moral diversity. Indeed, they demand that our moral commitment to civility be placed above all others. Is this asking too much? My critique here is not unlike Bernard Williams' famous critique of utilitarianism, namely that it is deeply flawed as a moral imperative because it requires moral agents to place utility above all other projects and values. Similarly, any Exceptionless Civility, regardless of its ground, requires moral agents to place civility above all other projects and values.

This is not only deeply troubling for the moral agent with other deeply held moral commitments, but also makes an idealized, generalized demand on moral agents with particularized commitments. Iris Marion Young, in Chapter 4 of Justice and the Politics of Difference, described this kind of demand to commit to a generalizable notion of the common good and subjugate the particulars of our own lives as part and parcel of "the ideal of impartiality" which "expresses a logic of identity that seeks to reduce differences to unity... The ideal of impartial moral reason corresponds to the Enlightenment ideal of the public realm of politics as attaining the universality of a general will that leaves difference, particularity, and the body behind... Recent attempts to revive Republican thinking appeal to the ideal of a civic public which transcends he particularities of interest and affiliation to seek a common good." (97) While impartiality is often considered part and parcel of a just and civil society 
precisely by dominant political theories, the totalizing impulse to place some notion of the "common good" above all other moral commitments is deeply problematic for moral agents.

Before we proceed, it is worth remembering that Young believes oppression, injustice, and other problems of social power track social groups and their members, rather than individuals per se. Such groups "do not exist apart from individuals" but "are socially prior to individuals, because people's identities are partly constituted by their group affiliations." (Young, 9) The totaling impulse to place the "common good" above all other deeply held moral commitments and projects places the individual moral agent in a sticky position: she cannot hope to assert that her own concerns, and those of the social group to which she belongs, are more important than the common good. In the case of Exceptionless Civility qua social stability, the ground of the claim that she cannot assert her particulars is precisely that the assertion itself is upsetting to the common good, which is social stability. Thus, the moral agent with the least power, often due to membership in particular social groups, is the least able to assert his or her particular needs and values.

This occurs not only because of the totalizing claim of commitment to social stability, but also because of the interplay between social stability-maintaining the status quo-and features of social power and oppression such as marginalization, powerlessness, and silence. The reader unfamiliar with marginalization and powerlessness can find an elaboration in Young, who calls these two "faces of oppression" out of a total of five which she identifies ${ }^{5}$. Briefly, marginalization involves members of oppressed social groups being pushed to the margins of society. Though Young focuses on participation in the labor, she says that "Marginalization is perhaps the most dangerous form of oppression. A whole category of people is expelled from useful participation in social life." (53) She is particularly concerned about the exclusion of persons from citizenship, likely by virtue of their economic dependency, but also

\footnotetext{
${ }^{5}$ These include exploitation, cultural imperialism, and violence. These have some bearing on civility, but the operations I am most concerned with here are those of marginalization and powerlessness.
} 
in general. For our purposes, let us extend marginalization to this broader notion of being excluded from citizenship and from the rights of redress and address that those who are counted fully citizens have, by right, as citizens. The second face of oppression which is relevant here is powerlessness. It is closely connected to marginalization, for "The powerless are those who lack authority or power... those over whom power is exercised without their exercising it; the powerless are situated so that they must take orders and rarely have the right to give them." (57) Powerlessness, Young notes, commonly leads to lack of respectability. Once one proves one has power, as when it is discovered that "this woman or that Puerto Rican man is a college teacher or business executive," people begin to behave more respectfully (58). Being powerless or perceived as powerless, one cannot command respect. We can see how this would be troubling in the case of demands for exceptionless civility: the powerless would be commanded to be civil and could not reciprocally command the same in return.

The marginalized and the powerless also cannot demand that they be heard. Paulo Friere introduces the notion of a "culture of silence" as a feature of oppression and power differentials. In a culture of silence, per Friere, oppressed peoples no longer talk about their oppression, certainly not outside of their social group and often not inside their social group. This is related to the well-known technique of silencing, much more easily done by those with the power to control speech and uptake of speech, and thus commonly used to reinforce existing power structures. Someone who is silenced cannot be heard, and those who control the norms of civility and can demand that others follow them can refuse to hear those who do not follow them. Silencing is one of many means of making people powerless, as is marginalization, and a punishment often used against those deemed uncivil as we shall soon see.

A clear example of the use of civility to maintain the status quo, thereby both keeping society stable and reinforcing existing power structures through marginalization, powerlessness, and silence, 
can be seen in a non-academic setting in which contentious issues are often raised: meetings of local government bodies. Bear with me as I draw out the details of this case. In May of 2014, the Supreme Court of the United States issued its ruling in the case Town of Greece v. Galloway. The case is based on a contested practice during town council meetings in the mostly Christian town of Greece, NY. In 1999, Greece began offering chaplain-led prayers before town council meetings. The council compiled a list of chaplains from which to draw, all of whom were Christian. As many as two-thirds of the invocations explicitly invoked Jesus Christ; this changed only in 2007 when complaints were lodged and nonChristian chaplains were occasionally invited (Lithwick). As Dahlia Lithwick explains:

Two women sued, one an atheist and the other a Jew, both contending that the First Amendment's Establishment Cause is violated when, as here, the state sanctions a system in which Christian prayers are offered almost exclusively for nearly a decade, particularly when this occurs at sessions in which citizens in attendance must participate in order to interact with their elected representatives. The $2^{\text {nd }}$ U.S. Circuit Court of Appeals agreed. Today, on the usual 5-4 lines, the Supreme Court reversed the appeals court, finding that even the overtly sectarian prayers offered in Greece do not violate the constitution and... that outside of future prayers that 'threaten damnation, or preach conversion,' neither state legislatures nor the judicial branch should play any role in second-guessing the religious leaders conducting prayer sessions... To the extent that court ever played a role in ensuring that minority religious rights were not trammeled by well-meaning majorities who fervently believe that here in American we are all basically just country-club Judeo-Christians with different hairstyles, the jig is up: From now on we just do as the religious majorities say, so long as nobody is being damned or converted.

Note the power relations inherent in the fact that the town of Greece is overwhelmingly Christian, that the prayers were once exclusively Christian and now still overwhelmingly Christian, and the Court's apparent lack of concern for this differential. In his concurring opinion with the majority, Supreme Court Justice Samuel Alito concludes that most of the invocations and religious intonation of the chaplains' prayers was polite and therefore "no tolerant, open-minded person should object" in 
Lithwick's words. In his own words, Alito wrote, "although the principal dissent attaches importance to the fact that guest chaplains in the town of Greece often began with the words 'Let us pray,' that is also commonplace and for many clergy, I suspect, almost reflexive." Lithwick points out the power differential problems here: "the assumption seems to be that since-left to their own devices-polite majority religions almost always inadvertently privilege themselves, there can be no real constitutional harm here ${ }^{6}$. He does not see that this is precisely the danger... Perhaps because [Kennedy and Alito's] version of religion is so polite, they've reimagined the refusal of dissenters to either pray along or remove themselves from the room... as civic rudeness." This attitude which Lithwick identifies in the concurring opinions in this case is also identified in Supreme Court Justice Elena Kagan's dissent. She points out that "when the plaintiffs began to voice the concern over prayers that excluded some Town residents, one pastor pointedly thanked the board '[on] behalf of all God-fearing people' for holding fast, and another declared the objectors 'in the minority and... ignorant of the history of our country." It appears to me that both the town and Justices Kennedy and Alito (in the majority and concurring opinions) view the plaintiffs as uncivil and misguided. By seeing the status quo as harmless, and the complaints of those against it as uncivil and misguided, social smoothing functions of civility are seen to reinforce existing power structures and to silence, marginalize, and strip the power to demand redress from those who contest the world as it is currently structured. Refused redress, the plaintiffs might well feel the need to be a tad bit uncivil in continuing to demand change that attends to their particulars rather than quashing them under generalizations.

In some cases, there is no necessary conflict between personal moral values and commitment to civility. Perhaps this is as it should be. Perhaps all matters of personal consciences should align with a

\footnotetext{
${ }^{6}$ This same assumption that religiously-based comments are "polite" was raised in the Supreme Court's 2014 decision to eliminate buffer zones around abortion clinics. These buffer zones were judged to hinder the free speech rights of those anti-abortion protesters who engaged in "quiet counseling." (Giacometti) Because it was quiet/polite and seemed to do no constitutional harm, the Court's majority found it to be constitutional. The reasoning is very similar to that in the Town of Greece vs. Galloway. Actual power differentials, or the reality of whether or not the speech is actually quiet or polite, seemed irrelevant to the majority.
} 
commitment to civility. But perhaps not. When the opposition does not listen or when the opposition is not civil, as with pro-life and pro-choice activists who call their opponents on their home phones and at all hours of day and night (Murdoch; Sun), or as with the Westboro Baptist Church's vehement protests and invective against homosexuals, feminists, and soldiers, it seems a great deal to ask that we ourselves should remain civil. Such Exceptionless Civility forces us into a kind of functional relativism in which we must tolerate even views which would impose an intolerable form of life upon us and those whose welfare is our concern. The plaintiffs in Town of Greece vs. Galloway are certainly being asked to do so. Those who must remain civil to the Phelps family, who constitute the entirety of the Westboro Baptist Church, are generally asked to do so. I do not mean to imply here that we must actually believe that our opponents' view is as legitimate as our own, simply that Exceptionless Civility requires that we act as if it were. Thus, a simplistic functional relativism is required in which we may well think intolerantly while being civil. This makes us unable to commit fully to our most deeply held moral particulars; we can think all we like, but cannot act.

Formal civility, itself, can lead to functional relativism in other ways, as well. Lawrence Nelson and Michael Meyer critique the President's Commission on Bioethics and argue that its emphasis on civility, combined with sharp disagreement on the moral issue of human embryonic stem cell research, meant that it "essentially failed to adequately engage and respectfully acknowledge each others' deepest moral concerns." (33) In the resulting report from the Commission, each position was simply described rather than dealt with, merely tolerated rather than seriously considered (Nelson and Meyer). This is very real case of how using the norms of formal civility to prevent conflict can result in functional relativism.

And so, we see some of the limitations of Exceptionless Civility. Yet Berlin's pluralism leaves room for us to attack-even war-against such views and, by extension, those who hold them. Can 
these notions be reconciled? Is pluralism a threat to civility? Must civility drive us to functional relativism?

To address these issues, we must consider, however briefly, whether there are grounds for a qualified civility that may be compatible with a pluralist view and allow us to avoid the functional relativism to which Exceptionless Civility condemns us. This is best done by considering further the ways in which existing power structures are served by some notions of civility, and whether any ground of substantive civility can justify exceptions to formal civility.

\section{Exceptions to Civility: How These and Other Critiques of Civility Can Lead Us to a Version Compatible with Pluralism}

To my knowledge, no critics of civility levy the critiques I levy above about the sticky position of moral agents in a morally diverse society, and the potential for functional relativism. However, other critiques may point the way to a more nuanced vision of civility.

Many critics have begun by noting that common conceptions of civility are purely formal in nature. This is easily seen in English-language dictionaries, one of which defines civility as "Formal politeness and courtesy in behavior or speech." Noted synonyms include "comity - urbanity complaisance." This latter synonym provides the greatest difficulty for critics working within power analysis, as complaisance cannot be an option for those seeking to overturn unjust power structures and to right moral wrongs. Dorothy Roberts, who has also analyzed race-based medicine, writes in line with some aspects of power and civility we have already considered. Roberts argues that civility is often used to hush up those, especially oppressed sexual or racial or class groups, who point out violations of lack of respect for themselves. Such discussions are deemed "inappropropriate" and cause social disruption. Thus, it is claimed, they are uncivil. When the demands of civility count only if initiated from the topdown, those on the bottom of a power structure-those who are powerless or at least have less 
power-lack the ability to make claims of civility on the powerful; only the powerful can make such claims. Indeed, this is precisely what one would expect of the way that formal civility and civility qua social stability would function in a society with power differentials: those differentials would be maintained as part of the status quo, and would affect the ability of those with less power to demand or effect change.

For similar reasons, the faculty union at University of Oregon objected to an element of the recent (2013) contract proposed by administration, namely that faculty communications be subject to a civility clause. Negative reaction was intense, as Corey Robin documents: "While it's hard to find people who are anti-civility, many academics note that requiring civility can become a tool for punishing those professors who speak out against their bosses or who push unpopular positions." Many respondents pointed out the power dynamics inherent in those with power being the ones to determine what constitutes civility. This draws attention to who deems discussions to be "inappropriate" and socially disruptive. So intense was the faculty response at $U$ of $O$ that the university pulled the proposal. Scott Pratt of the University of Oregon stated that one of the faculty's counter offers had included a requirement that the civility clause be two-way, e.g. that the administration could be judged to be uncivil by the faculty and therefore in violation of their end of the contract. The administration dropped the clause rather than allow reciprocity. As Pratt noted during discussion of an earlier draft of this paper, this raises the possibility that it is lack of reciprocity that creates the real problem for Exceptionless Civility. This is entirely consistent with the analysis of power and civility that I have laid out here, and which presents real problems for pluralism and the ability to defend one's view against those who find it intolerable or whose views one finds intolerable.

One possible problem for seeking any exceptions to demands for civility is that, if the demand were universally applied and enforced, it could protect the most vulnerable among us. Indeed, Bonnie 
Mann argued during discussion of an earlier draft of this paper that reciprocal, mutually binding Exceptionless Civility is one of the few protections for vulnerable persons in a diverse society. By way of example, she mentioned high school students who are bullied for being different from their peers, bullied not only by physical means but by use of language and social manipulation. I grant that this clearly violates formal civility regardless of its ground, and substantive civility where the ground is respect for persons. It does seem to be a problem that could be fixed by Exceptionless Civility. But I do not think that this can be the answer because Exceptionless Civility gives rise to such difficulties for precisely those vulnerable persons, difficulties which are nicely described by Roberts and Mayo.

On such grounds, even the famous "civil disobedience" of the Freedom Riders would be uncivil. The Freedom Riders chose to travel across state lines on buses during civil rights movement in order to test state laws about segregation of transportation which forced people of color to ride differently than their white counterparts. They did so in hopes of forcing a federal response to state laws that affected interstate transportation. When stopped at state lines or bus depots and arrested, the Freedom Riders went unprotestingly into paddy wagons and filled jails to capacity and beyond until they were tried or released. Despite the Freedom Riders' civil disobedience, as embodied in their respect for the authority of the state to impose penalties on those who violate unjust laws, they were clearly and deliberately both inappropriate and socially disruptive, speaking out against power and pushing unpopular positions.

This can happen even within movements that contest the status quo. Movements such as feminism contain diverse viewpoints, but the concerns of some can be totalized and made universal. We see this in the classic complaints levied by bell hooks in her famous use of the refrain "Ain't I A Woman?", and by Audre Lorde, that feminism has not adequately addressed the concerns of black women or included black women, themselves, in the movement. There are other issues of the inclusion of particulars, as well. We hear calls for feminists to question their emphasis on the concerns of 
cisgender women to the exclusion of those of trans* women, to question their emphasis on reproduction from the heterosexual view and instead to better include the concerns of lesbian and bisexual women, to incorporate women of color generally including Latina women, Asian women, African-American women, and Native American women as well as others. Lorde herself wrote on the legitimate anger, an entirely appropriate reaction, she felt at her exclusion as a result of her race, and on the reactions of white feminists to being called out for their own participation in and lack of resistance to white supremacy. She provides a bulleted list of some examples of her anger, and the reaction of others to it, in her deservedly famous piece "The Uses of Anger". The first example is this: "I speak out of direct and particular anger at an academic conference, and a white woman says, 'Tell me how you feel but don't say it too harshly or I cannot hear you.'" (Lorde, 278)

This kind of reaction on the part of the white woman is precisely a civility reaction: tone down your rhetoric otherwise I am entitled to ignore you. Abide by formal civility or you will have abrogated your right to be heard. This demand for civility no matter what is precisely a demand for exceptionless civility, and also shows how closely such demands are tied to silencing and lack of respect. Yet with an issue such as racism, the toned-up rhetoric which is perceived as uncivil may be the only appropriate one. Lorde says, "Women responding to racism means women responding to anger; Anger of exclusion, of unquestioned privilege, of racial distortions, of silence, ill-use, stereotyping, defensiveness, misnaming, betrayal, and co-optation." (ibid.)

To demand civility in the face of this is in fact to demand that the complainant soft-pedal and downplay the impact of the system on particular individuals and their particular concerns. The appropriate response in such a situation is not, when one is in the dominant power position, to say the person in the subordinate power position, "be civil or I cannot hear you." This reinforces marginalization and powerlessness through silencing. Lorde goes on to essentially urge women, and women of color, to 
be uncivil in their demands for redress of their particulars: “...anger expressed and translated into action in the service of our vision and our future is a liberating and strengthening act of clarification, for it is in the painful process of this translation that we identify who are our allies with whom we have grave differences, and who are our genuine enemies." (280; my emphasis) No matter how uncivil, anger has its uses. To demand that a person not be angry when they have every reason to be is to silence them and show lack of respect. In a sense, the very demand for formal civility-to not show anger, to moderate your tone, etc. - contradicts the ground of civility qua respect for persons, though not of civility qua social stability.

Such critiques of other are still violating formal civility in the internet era, but with a corresponding benefit. As Veronica Bayetti Flores points out, so-called "twitter feminism" and the use of other internet media, for all its reputation as the "wild west" of the internet in terms of lack of civility and rudeness, has given a megaphone to people who had none:

Yes, we have a lot to learn about treating each other with dignity when we aren't experiencing each other in person. But internet feminism, including twitter, has also given a platform to voices we would rarely have heard from otherwise, has created community for folks in places or circumstances where finding each other is difficult, and has catapulted historically marginalized conversations into the mainstream. This is a fact that cannot be ignored, and to suggest that a feminist space that has fostered and amplified voices of women of color is toxic in its entirety is misguided at its very best. And let's not pretend like folks consistently see each others' full humanity in person either. This is about our movements everywhere. (Flores)

The sub-culture of feminists, the progressive movement, has its own status quo which is preserved by calls to dissidents within the movement to be civil, to keep a civil tongue in their head, to not be so angry.

This is also true of anti-racist movements, where women's issues are often ignored and a certain kind of problem is universalized as the one which requires action. This occurred during and within the 
civil rights movement. It occurs still, as was pointed out in response to President' Obama's focus on the problems of young black men in his My Brother's Keeper initiative. What about "My Sister's Keeper"? asked some, as more than 1,000 women of color signed a letter asking for gender parity in the program (Henderson). Noted feminist Kimberle Crenshaw discussed the issue in a July 2014 op-ed, calling the program "an abandonment of women of color" and suggesting that, "Perhaps the exclusion of women and girls is the price to be paid for any race-focused initiative in this era." (A23) How do we hold each other accountable? How do we distinguish between a violation of civility which is called for and one which is uncalled for? As Flores says, "Calling folks out in good faith-or calling in-is necessary." By "calling in", she means to use a notion discussed by Ngoc Loan Tran. Tran develops an idea of "calling in", in which we acknowledge that even those of us who have learned to account for the unheard voices, and indeed to hear them speak for themselves, didn't always know this. Rather than calling out those who don't know it, we should call them in, invite them in to the space where one learns this. Those who aren't doing a good enough job yet, says Tran, cannot be treated as "disposable" allies, to be thrown away when they aren't doing it right: "We have to let go of treating each other like not knowing, making mistakes, and saying the wrong thing make it impossible for us to ever do the right things." And so, in the terms I have been using, we might say that call people "in" because we demand respect for ourselves and a hearing for the unheard, and we do it in this way because the people we are critiquing are ones who share most of our values - the mainstream feminists, the anti-racists - and are themselves persons and deserve respect. But that does not necessarily mean they deserve a smooth and untroubling social interaction. As Lorde noted, one of the uses of anger is that we can learn from it, that it can be used for growth. The alleged "common good" of a stable society or avoiding the appearance of internal conflict within a movement should not trump the need to reform society or a movement to be one that better respects persons and allows individuals to pursue their own vision of the good and have their own particular concerns given weight. That would place civility and pluralism forever at odds. 
At this point, I wish to draw the alert reader's attention to the fact that much of the framing of the issue of formal civility so far relies upon the substantive ground of civility qua social-stability (the notion underlying those who wish to suppress dissent). Drawing on Roberts, Cris Mayo notes that the social "smoothing" functions of etiquette cover up legitimate social problems which must be dealt with in order to have justice and respect for persons. This is precisely what we have seen in some of the previous examples. Mayo himself provides us with the thought-provoking example of "heinously nonconformist kids" - often gay or gender queer - in public schools being warned to conform by their selfavowedly liberal teachers (175). He also raises something we may all have witnessed: the common occurrence in graduate seminars in which members of minorities who point out that frameworks presented by theoreticians and professors harm them or others are, in turn, silenced and told they are "making a mountain out of a molehill" or other dismissive terminology which reads as "causing trouble." By making such claims or by not conforming, students are "making an issue of something that, in polite society, ought to be ignored." (Mayo 174)

So we see that civility can be used to silence those with less social power on the grounds of both how they present what they say, and the topics which they raise. We have seen not only that this can happen in the context of mainstream society but also in the context of progressive movements.

I contend that civility qua social stability will give rise to Exceptionless Civility through the pursuit of order and social smoothing. However, civility qua respect for persons need not do so.

\begin{tabular}{|l|l|l|}
\cline { 2 - 3 } \multicolumn{1}{c|}{} & $\begin{array}{l}\text { Exceptionless } \\
\text { Incompatible with pluralism }\end{array}$ & $\begin{array}{l}\text { Qualified } \\
\text { Compatible with Pluralism }\end{array}$ \\
\hline Civility qua respect for persons & Possible & Recommended \\
\hline Civility qua social stability & Always & Impossible \\
\hline
\end{tabular}

Indeed, respect for persons ought precisely to support heinously non-conformist kids in their violations of formal civility, ought precisely to support minority critiques of frameworks. It is possible to interpret 
civility qua respect for persons in such a way that not only need it not give rise to Exceptionless Civility, but that it must not do so. Any exceptions to formal civility must, however, be grounded back to the substantive notion of respect for persons. Now let us return to Bonnie Mann's example of a bullied high school student whose welfare might be greatly helped by a demand for social stability. If the qualification for an exception to formal civility is that it preserves the substantive ground of civility qua respect for persons, then that student's peers who engage in bullying are engaging in an unjustified violation of formal civility: their actions not only do not preserve respect for persons, but in fact undermine it. Social disruptions and inappropriate behavior may well be justifiable on the same grounds which generally rule out socially disruptive and inappropriate behavior: respect for persons. Social disruptions and inappropriate behavior which do not embody respect for persons would constitute unjustified exceptions to formal civility.

Using the conceptual tools we acquired from Boyd, we can see that the criticisms I have levied and synthesized boil down to the fact that Formal Civility can cover up violations of Substantive Civility. What is really going on here is less a critique of civility per se than a critique of particularly shallow notions of civility, and of the substantive notion of civility qua social stability. Indeed, these points ought to make us careful of a slavish adherence to formal civility and of the notion of civility qua social stability. Roberts and Mayo might both be copacetic with a revision of civility grounded in respect for persons. Nonetheless, what this critique implies is that formal incivility is permissible and even admirable when it draws attentions to violations of substantive civility: the "heinously nonconformist kid" and the disruptive minority graduate student are both demanding their right to pursue the good. So, we see that some apparent violations of civility are in fact in keeping with the spirit of civility qua respect-for-persons. From this, we may derive a sort of rule-a guideline, really-for violating formal civility. Call this the Acceptable Exceptions rule: 
Violations of formal civility are acceptable if and only if they are required to preserve the substantive ground of civility qua respect for persons. When this is the case, they are not only acceptable, but necessary.

\section{Conclusion}

I remain concerned that exceptionless civility drives us to a functional relativism rather than the pluralism necessary for moral agents to function in a morally diverse society. I remain concerned about the demands civility places on moral agents facing values which, if put into practice by their adherents, make tolerable forms of life impossible. Any acceptable view will allow exceptions to formal civility in support of the substantive notion of civility which underpins it. Since I contend that civility qua social stability demands exceptionless civility, the remaining substantive notion of civility must either be civility qua respect for persons or some other morally rich notion of civility compatible with the creation of a morally desirable society that allows the pursuit of plural ends. I do believe we have made progress wading through the issues and the end is in sight. To that end, I wish now to reframe and expand upon some of the questions I asked earlier.

Can civility qua respect for persons cohere with a pluralism which allows us to go so far as to attack other views? I believe it can, since we can violate formal civility to preserve its substance as layed out in the Acceptable Exceptions rule. Can it be made compatible with a pluralism which allows us to go so far as war with other views, and their adherents? Perhaps, though there will be constraints on how that war is waged imposed by the ground of respect even for persons with whom we profoundly disagree. Can civility qua social-stability cohere with a pluralism which allows us to go to war with other views, and their adherents? Never. But a qualified civility grounded in respect for persons can. It asks just what must be asked, rather than too much.

\section{Acknowledgements}


I would like to thank the audience for my presentation of this paper at FEAST 2013 in Tempe, Arizona. Scott Pratt and Bonnie Mann in particular pushed me, respectively, on the importance of reciprocity in civility and on the potential need for exceptionless civility in protecting vulnerable persons. These points have been incorporated into the paper, as have critical points levied by the editors of this issue.

\section{BIBLIOGRAPHY}

Isaiah Berlin. "The First and the Last." New York Review of Books. May 14, 1998.

Amy Bingham. "Rush Limbaugh: Over 40 Advertisers Flee, Host Says 'Everything's Cool'." ABCnews.go.com. March 7, 2012.

Richard Boyd. "The Value of Civility?" Urban Studies 43(5/6): 863-878. 2006.

Kimberle Williams Crenshaw. "The Girls Obama Forgot." The New York Times. July 29, 2014. Page A23.

Veronica Bayetti Flores. "On cynicism, calling out, and creating movements that don't leave our people behind." Feministing.com. December 20, 2013.

P.M. Forni. Choosing Civility: The Twenty-Five Rules of Considerate Conduct. St. Martin's Press: New York. 2002.

Paulo Friere. The Politics of Education. Trans. Donaldo Macedo. Bergi \& Garvey: London. 1921.

Robert George. "Book Review: Law, Democracy, and Moral Disagreement." Harvard Law Review 110(7): 1388-1406. 1997.

Brian Giacometti. "Buffer Zones, Clinic Escorting, and the Myth of the Quiet Sidewalk Counselors." Huffingtonpost.com. July 7, 2014.

Laurie Goodstein. “Founder of 'Civility Project' Calls It Quits.” The New York Times. January 12, 2011.

Amy Gutmann and Dennis Thompson. Democracy and Disagreement: Why Moral Conflict Cannot Be Avoided in Politics, and What Should Be Done About It. The Belknap Press of Harvard University:

Cambridge. 1996.

Nia-Malika Henderson. "1,000 women of color want women and girls included in 'My Brother's Keeper'." The Washington Post.com. June 18, 2014.

Thomas Hobbes. Leviathan. Ed. CB Macpherson. Penguin Classics: London. 1968.

bell hooks. Ain't I A Woman: Black Women and Feminism. Pluto Press: London. 1982.

Dahlia Lithwick. "Let Us Pray." Slate. May 5, 2014. 
John Locke. Second Treatise of Government. Ed. CB Macpherson. Hackett Publishing Co: Indianapolis. 1980.

Audre Lorde. "The Uses of Anger: Women Responding to Racism." Women's Studies Quarterly 25(1/2): 278-285.

Cris Mayo. "The Binds That Tie: Civility and Social Difference." Educational Theory 52(2): 169-186. 2002.

Michael McConnell. "Don't Neglect the Little Platoons." In For Love of Country: Debating the Limits of Patriotism. Ed. Joshua Cohen. Beacon Press: Boston. 1996. pp78-84.

Cassie Murdoch. "Payback Is a Bitch for Abortion Clinic Protestors, Thanks to a Brilliant Landlord." Jezebel.com. March 30, 2012.

Lawrence Nelson and Michael Meyer. "Confronting Deep Moral Disagreement: The President's Council on Bioethics, Moral Status, and Human Embryos." American Journal of Bioethics 5(6): 33-42. 2005.

Martha Nussbaum. "Patriotism and Cosmopolitanism." In For Love of Country: Debating the Limits of Patriotism. Ed. Joshua Cohen. Beacon Press: Boston. 1996. pp2-20.

Stephen Prothero. "My Take: Georgetown backs Fluke vs. Limbaugh for Civility's Sake." CNN.com. March 4, 2012.

Lucian Pye. "Civility, Social Capital, and Civil Society: Three Powerful Concepts for Explaining Asia." Journal of Interdisciplinary History 29(4): 763-782. 1999.

Corey Robin. "University of Oregon to Faculty: You Belong to Me!" September 15, 2013. http://coreyrobin.com/2013/09/15/university-of-oregon-to-faculty-you-belong-to-me/

Michael E. Ruane. "Bikers protest Westboro Baptist demonstrators at Arlington burial." The Washington Post. October 4, 2010.

Janese Silvey. "'Red Wall' of supporters comforts fallen soldier's family." Columbia Daily Tribune. July 21, 2012.

Lena H. Sun. "Anti-abortion protesters target clinic's landlord outside child's Md. School." The Washington Post. September 12, 2011.

Ngoc Loan Tran. "Calling IN: A Less Disposable Way of Holding Each Other Accountable." Black Girl Dangerous. December 18, 2013.

Iris Marion Young. Justice and the Politics of Difference. Princeton University Press: Princeton, NJ. 2011. 